\title{
Micro-organisms Associated with Plant Buds
}

\author{
By C. LEBEN \\ Department of Plant Pathology, Ohio Agricultural Research and Development Center, \\ Wooster, Ohio 44691, and The Ohio State University, Columbus, Ohio, U.S.A.
}

(Accepted for publication 2 February 1972)

SUMMARY

Macerates of buds of apple, cottonwood and white pine were cultured for bacteria, fungi and yeasts periodically during the spring. Fewer than 1000 propagules of each were found in most buds. As the growing season progressed, the surface of parts of buds of herbaceous plants and grape was examined microscopically for micro-organisms. Fungi and yeasts were rare. Numbers of bacteria were seen on $>60 \%$ of the buds of red clover, soybean, cucumber, turnip and grape. Macerated parts of soybean plants from the field and greenhouse were assayed in vitro for bacteria. Large numbers of bacteria were associated with buds, flowers and small pods from field plants, and comparatively few were associated with mature leaves. In contrast, few bacteria were associated with any of these organs from greenhouse plants.

\section{INTRODUCTION}

Many investigations have been concerned with the microbiology of the phyllosphere (Last \& Deighton, 1965; Leben, 1965; Ruinen, 196I; Sinha, 1965). The bud habitat - the gemmisphere - has been scrutinized as a source of leaf organisms. This work has been reviewed recently (Leben, 197I). Thus, it has been found that buds of some field plants often carry sizeable populations of apparently harmless bacteria and yeasts. The site of overwintering yeasts important in apple-cider production is indicated to be the bud. Under experimental conditions, at least, pathogenic and non-pathogenic bacteria have been shown to multiply in the gemmisphere and to be transported upward as the plant grows. Moreover, there is evidence that the leaf-nodule bacteria of some tropical plants are passed from plant generation to generation via the seed through the flower bud. These results, then, suggest that the bud occupies an important and perhaps central position in the association of microorganisms with the aerial parts of some plants.

The present investigation was undertaken to obtain information on micro-organisms associated with buds of a few of the common woody and herbaceous plants in north-central Ohio. Studies with soyabean are stressed: a comparison of numbers of bacteria associated with aerial parts of plants grown in the field and in the greenhouse is presented.

\section{METHODS}

Two methods were used: direct microscopic observation of the surface of bud parts and culturing of macerated plant organs in vitro. Each has advantages and limitations (Leben, I971).

Microscopic observations of the surface of bleached and stained bud parts were made as described by Daft \& Leben (I966). Bud parts were separated under a dissecting microscope and attached to 'double-stick' transparent tape on microscope slides for bleaching, staining 
Table 1. Numbers of propagules of bacteria, fungi and yeasts in tree buds,* as determined in vitro

\begin{tabular}{|c|c|c|c|c|c|c|c|c|c|c|c|c|}
\hline \multirow[b]{2}{*}{$\begin{array}{l}\text { Collection } \\
\text { date }\end{array}$} & \multicolumn{4}{|c|}{ Apple } & \multicolumn{4}{|c|}{ Cottonwood } & \multicolumn{4}{|c|}{ White pine } \\
\hline & $\begin{array}{l}\text { Average } \\
\text { bud (gt) }\end{array}$ & $\begin{array}{c}\mathrm{B} \dagger \\
\text { (average }\end{array}$ & $\begin{array}{l}\mathrm{F} \dagger \\
\text { no. }\end{array}$ & $\begin{array}{c}\mathrm{Y}^{\dagger} \\
\left.\mathrm{IO}^{3} / \mathrm{g}\right)\end{array}$ & $\begin{array}{l}\text { Average } \\
\text { bud (g) }\end{array}$ & $\begin{array}{c}\text { B } \\
\text { (averag }\end{array}$ & $\begin{array}{c}F \\
\text { ge no. I }\end{array}$ & $\begin{array}{c}Y \\
\left.0^{3} / g\right)\end{array}$ & $\begin{array}{r}\text { Average } \\
\text { bud (g) }\end{array}$ & $\begin{array}{c}\text { B } \\
\text { (avera }\end{array}$ & $\begin{array}{c}\text { F } \\
\text { ge no. }\end{array}$ & $\begin{array}{c}Y \\
\left.10^{3} / g\right)\end{array}$ \\
\hline 2 I April & 0.2 & $<0.0$ I & $4 \cdot 7$ & $4 \cdot 8$ & 0.3 & $<0.01<$ & $<0.0 \mathrm{I}$ & 33 & 0.05 & $<0.01$ & $\mathrm{I} \cdot 5$ & 0.4 \\
\hline 28 April & 0.7 & $I \cdot I$ & $4 \cdot 7$ & I. 4 & 0.4 & 8 & 20 & 77 & 0.06 & $2 \cdot 5$ & 0.2 & $3 \cdot 7$ \\
\hline 5 May & 0.3 & 0.2 & 0.5 & 0.5 & $0 \cdot i$ & 0.02 & 0.1 & $\mathrm{I} \cdot 8$ & 0.4 & 0.2 & $I \cdot 9$ & $7 \cdot 0$ \\
\hline I2 May & $0 \cdot 2$ & 0.3 & 0.2 & 0.6 & $0 \cdot 1$ & 0.4 & 0.03 & 0.3 & 0.6 & I 30 & 0.9 & 55 \\
\hline I9 May & 0.3 & 0.4 & 0.1 & $0 \cdot I$ & 0.3 & $9 \cdot 4$ & 0.2 & $2 \cdot 8$ & $\mathrm{I} \cdot 3$ & 0.1 & $0 \cdot 6$ & I 6 \\
\hline 27 May & 0.3 & 0.2 & 0.1 & $0 \cdot I$ & 0.7 & 20 & 0.1 & 4 & $\mathrm{I} \S$ & 3 & $5 \cdot 7$ & 24 \\
\hline
\end{tabular}

* See text for definition of 'bud'.

$\dagger \mathrm{B}=$ bacteria, $\mathrm{F}=$ fungi, $\mathrm{Y}=$ yeasts. Four to five buds/plant species were assayed separately at each April sampling, and nine to ten were assayed at each May sampling.

\pm Wet weight. $6 \mathrm{~g}$

$\S$ Buds (candles) were so large that only the tip 2 to $3 \mathrm{~cm}$ was sampled. The entire candle weighed about

and observation at about $\mathrm{I} 200 \times$ magnification. Usually the stipule was observed, because this structure usually provided the best material for examination (i.e. stipules bleached better, were thinner, or had fewer trichomes). If micro-organisms were not detected in the examination time allotted for each bud (about five min), the bud was considered negative. Bacteria often were in groups. Buds were categorized as not bearing bacteria if objects which in fact may have been bacteria were few and scattered.

In the second method, macerated plant organs were cultured on media favouring the growth of plant-associated bacteria, yeasts, or fungi. The basal medium contained (final concentration, g/l): peptone, I0; casein hydrolysate, I; glucose, 5; and agar, 20. For the culturing of bacteria, $50 \mathrm{mg}$ of cycloheximide/1 were added to the basal medium before autoclaving, and $50 \mathrm{mg}$ of 2,3,5-triphenyl-2H-tetrazolium chloride/1 were added to the cooled medium after autoclaving and before pouring plates. (This bacterial medium, 'TTCC', has been used extensively in this laboratory for the study of pathogenic and nonpathogenic bacteria associated with plants.) In making the fungal medium, I00 mg chlorotetracycline $\mathrm{HCl} / 1$ were added to the cooled basal medium before pouring plates. Incubation times for both bacteria and fungi were two to three days at $24{ }^{\circ} \mathrm{C}$. In the preparation of the yeast medium, the cooled fungal medium was adjusted with $\mathrm{I} \mathrm{N}_{\mathrm{N}} \mathrm{H}_{2} \mathrm{SO}_{4}$ to $\mathrm{pH} 4.4$ to 4.8 before pouring plates. Incubation time for yeasts was seven days at $\mathrm{I} 6{ }^{\circ} \mathrm{C}$. Colonies were not categorized as yeasts unless budding cells were observed.

For assays in vitro, plant organs were collected and, within I to $2 \mathrm{~h}$, were ground in mortars containing 2 to $10 \mathrm{ml}$ of water and about $60 \mathrm{mg}$ of Carborundum $(600 \mathrm{mesh}$, Carborundum Company, Niagara Falls, New York, U.S.A.). Resulting suspensions were used to make Io-fold serial dilutions in water; a O. I $\mathrm{ml}$ sample of each dilution was spread on the surface of agar in each of three replicate Petri plates. Aseptic methods were used in these procedures.

Terminal 'buds' of herbaceous plants were defined as all parts $<2 \cdot 0 \mathrm{~cm}$ in length $(<\mathrm{I} \cdot 5 \mathrm{~cm}$ with soybean). Some samples contained small flower buds and other structures. The terminal 'buds' of woody plants were $<2.0 \mathrm{~cm}$ in length and were from lateral branches. The white pine 'bud' was the entire 'candle' from a branch, except as noted. At the final collection date (Table I), candles were 8 to $12 \mathrm{~cm}$ long and most branches of apple and cottonwood had ceased to elongate. 
Table 2. Bacteria observed by microscopy on parts of terminal buds of field plants

\begin{tabular}{|c|c|c|c|c|}
\hline Plant & $\begin{array}{l}\text { Examination } \\
\text { period }\end{array}$ & $\begin{array}{c}\text { Examination } \\
\text { dates* } \\
\text { (no.) }\end{array}$ & $\begin{array}{c}\text { Buds } \\
\text { examined } \\
\text { (no.) }\end{array}$ & $\begin{array}{c}\text { Buds bearing } \\
\text { bacteria } \\
(\%)\end{array}$ \\
\hline Red clover (Trifolium pratense L.) ${ }^{\dagger}$ & 17 June-8 August & 8 & 45 & 100 \\
\hline $\begin{array}{l}\text { Morning glory (Ipomoea purpurea } \\
\text { L.)§ }\end{array}$ & 23 June & 1 & 3 & 100 \\
\hline Soybean (Glycine max L.) & I 7 June-8 August & 9 & 49 & 92 \\
\hline Cucumber (Cucumis sativus L.) & I4 July-8 August & 5 & 30 & 87 \\
\hline Turnip (Barssica rapa L.) & I 7 June-8 August & 8 & 28 & $7 I$ \\
\hline Grape (Vitis vinifera L.) & 29 June-8 August & 7 & 32 & 66 \\
\hline Soybean (flower) $t$ & 6 July-8 August & 6 & 30 & 43 \\
\hline $\begin{array}{l}\text { Tomato (Lycopersicon esculentum } \\
\text { Mill.) }\end{array}$ & I7 June-8 August & 8 & 25 & 24 \\
\hline Alfalfa (Medicago sativa L.) & 17 June-8 August & 6 & 22 & 23 \\
\hline $\begin{array}{l}\text { Lima bean (Phaseolus limensis } \\
\text { Macf.) }\end{array}$ & 23 June-6 July & 3 & 6 & 17 \\
\hline Pepper (Capsicum frutescens L.) & 17 June-23 June & 2 & 6 & o \\
\hline $\begin{array}{l}\text { Ragweed (Ambrosia artemisiifolia } \\
\text { L.) }\end{array}$ & I 7 June & I & 3 & o \\
\hline
\end{tabular}

Field and greenhouse soybean plants were from one seed lot of the HAROSOY 63 cultivar. Field plants were in rows $2 \mathrm{~m}$ apart; there were 10 to 15 plants $/ \mathrm{m}$ within rows. This wide spacing exposed lower leaves of mature plants to sunshine and air movements. Organs of field plants were assayed from 27 July to 27 August, when plants were 70 to $90 \mathrm{~cm}$ high. In the greenhouse, individual plants were grown in large pots during the autumn and winter months, when the air within the house was at a relative humidity of 30 to $50 \%$. Care was taken to avoid wetting the foliage during watering. Plants were $\mathrm{I}$ to $2 \mathrm{~m}$ high when organs were assayed in vitro.

\section{RESULTS}

Micro-organisms associated with buds of trees. Preliminary studies in early spring, I970, indicated that few organisms were to be seen by microscopic observation of parts of opening buds of several tree species growing in the field. To obtain more information, buds of apple (Malus sylvestris Mill.), cottonwood (Populus deltoides Marsh.) and white pine (Pinus strobus L.) were cultured periodically as the season progressed.

Results of assays in vitro are given in Table I. Most buds carried $<1000$ propagules of bacteria, fungi or yeasts, although in some buds up to $4 \times 10^{4}$ propagules were found. Populations of bacteria were low, especially in comparison with those in field soybean plants (see below). A variety of colony types was observed within each group. A pattern of types did not appear to be present. In general, tree buds were more difficult to macerate than those of herbaceous plants; consequently groups of some organisms may have been counted as single propagules.

Micro-organisms associated with buds of other field plants. At 4- to 14-day intervals from June to August 1970, bud parts of miscellaneous plants were examined microscopically. Usually three buds of a species were examined at one or two dates, and, if no micro-organisms were observed, examinations were discontinued. If micro-organisms were observed, the numbers of buds sampled were usually increased and examinations were continued.

Since there were no apparent seasonal trends in the results, data for the entire season are 
given in Table 2. These data are for bacteria only, because fungal hyphae were observed rarely and large cells that may have been yeasts were seen infrequently (no cells of this type had budded). Bacteria were observed on all red clover and morning glory buds and on $>60 \%$ of the soybean, cucumber, turnip and grape buds. Bacteria were observed also on soybean sepals and corollas. These organisms usually were easily seen in dispersed groups or in masses on most specimens: nearly all bacteria were short rods. The reasons for the low populations of fungi and yeasts are not understood; in buds of woody plants members of these groups appeared to be more prevalent (Table I).

Numbers of bacteria associated with different parts of soybean plants in the field and greenhouse. Various organs of field plants collected at eight dates in the last weeks of July 1970 were assayed in vitro. Plants were 0.8 to I $\mathrm{m}$ high. Numbers of bacteria from a representative plant of the ten studied were (in millions/g wet weight of plant tissue): terminal bud, 20; leaf I (partly folded, $2.4 \mathrm{~cm}$ long), I 5 ; leaf 2 (about half size), 3 ; leaf 3 (nearly full size), 0.1 ; leaves 4 to Io (full size, about $15 \times 20 \mathrm{~cm}$, excluding petiole), 0.03 to $\mathrm{I} \cdot 4$ (most full size leaves of all plants assayed carried $<0 \cdot \mathrm{I})$; flowers (violet-coloured corolla exposed), $5 \cdot 2$; fertilized flowers (corolla withered), 24 ; and young pods (I to $2.5 \mathrm{~cm} \mathrm{long}$ ), 54 . A variety of bacterial colony types was isolated from most samples; types did not appear to be associated with particular plants or organs. Thus, the older, lower leaves carried few bacteria in comparison with young organs. The influence of weather on this distribution is not known - I970 was a comparatively 'dry' year. In other studies of buds of field plants in 1968 and I970, most of the 440 buds assayed carried $10^{6}$ to $10^{7}$ bacteria/g (C. Leben, unpublished results).

Markedly fewer bacteria were isolated from greenhouse plants. The terminal buds, leaves of various ages, flowers, and young pods of I4 plants collected at nine times were examined. These organs were about the same size as those of field plants, but they weighed less. Each of seven terminal buds carried < 180 bacteria/g (wet weight), and seven carried 200 to $5000 / g$. Four flowers from one plant were pooled for assay. Nine such lots each carried $<45^{\circ}$ bacteria/g. Four pods from a plant likewise were pooled and assayed. Each pod lot carried $<100$ bacteria/g. The leaf with the largest population bore only $7 \times 10^{3}$ bacteria/g, and $7 \mathrm{I}$ of the $9 \mathrm{I}$ leaves assayed carried $<\mathrm{I00}$ bacteria/g. Numbers of bacteria did not appear to be related to leaf position on the plant.

The low numbers of bacteria associated with terminal buds of greenhouse plants confirm other work (Sleesman, Leben, Schmitthenner \& Coyle, 1969).

It is noteworthy that cucumber buds, which carried many bacteria when plants were field-grown (Table 2), bore few bacteria when plants were produced in the greenhouse. Thus, in assays of 22 terminal buds in vitro from greenhouse seedlings $<100$ bacteria/bud were detected.

\section{DISCUSSION}

These studies demonstrated that, in the field, buds of some plant species - especially cucumber, red clover and soybean - supported large numbers of bacteria. On the other hand, buds of other species appeared to carry few bacteria. For example, relatively few were found in buds of two deciduous trees, results that confirm those of Keener (I950, I95I). Likewise low numbers of yeasts and fungi were associated with tree buds. Presumably the large numbers of bacteria associated with buds of some plants were not harmful to the plant; indeed, it would be of interest to know if they served a useful function.

Under our field conditions, the soybean bud appeared to be a centre of bacteriological activity. Many more bacteria were associated with buds and other young developing organs than with mature leaves. Even so, a healthy mature leaf may bear several thousand bacteria, which then may serve as a source for future bacterial growth when conditions are favourable 
as has been reported with field cucumber leaves (Leben \& Daft, 1967). Probably most of the bacteria in the soybean gemmisphere are on the surface of bud parts, where they were observed in large numbers. Often they were in aggregations, indicating that they were multiplying and were not casuals, i.e. deposited by chance from air or by insects and other agencies. Since few bacteria appear to be associated with mature field leaves, they may be within leaves (Barnes, 1965) or scattered in protected positions. The numbers of bacteria in buds and their scarcity on leaves suggest that a portion of the phyllosphere bacteria may be derived from those living in the bud.

The reason for there being low numbers of bacteria in buds of greenhouse-grown plants is not known. Probably the comparatively dry conditions of the greenhouse were responsible, since a high humidity and free water favour the growth of all types of epiphytic flora (Leben, 1965). Under our conditions, plants in the open are subjected to many nights of high humidity and dew and to intermittent rains.

The high number of bacteria associated with flowers and pods of field soybean plants suggests the possibility that some of these organisms may come to rest in or on the seed and be transmitted to buds of the next plant generation. Seed from the greenhouse would be expected to carry few bacteria, including pathogens. My colleagues have used the greenhouse to produce mung bean seeds that apparently do not carry Pseudomonas phaseolicola (Schmitthenner, Hoitink \& Kroetz, 1971).

Micro-organisms that were isolated were identified only as bacteria, fungi or yeasts. A multiplicity of bacterial colony types was found, as has been the experience in other work with bacterial residents (Leben, 1965, 197I).

Published with the approval of the Director of the Ohio Agricultural Research and Development Center as Journal Article no. 22-7I. The technical assistance of William R. Beery is gratefully acknowledged. I thank G. C. Daft and Raymond Louie, Jun. for their assistance. I am indebted to R. R. Davenport for suggestions on culturing plant-associated yeasts.

\section{REFERENCES}

BARNes, E. H. (I965). Bacteria on leaf surfaces and intercellular leaf spaces. Science, New York 147, I I5III 52.

DAFT, G. C. \& LEBEN, C. (1966). A method for bleaching leaves for microscope investigation of microflora on the leaf surface. Plant Disease Reporter 5o, 493.

KeENER, P. D. (1950). Mycoflora of buds. I. Results of cultures from non-irradiated materials of certain woody plants. American Journal of Botany 37, 520-527.

KEENER, P. D. (195I). Mycoflora of buds. II. Results of histological studies of non-irradiated buds of certain woody plants. American Journal of Botany 38, I05-I 10.

LAST, F. T. \& DeIGHTON, F. C. (1965). The non-parasitic microflora on the surfaces of living leaves. Transactions of the British Mycological Society 48, 83-99.

Leben, C. (1965). Epiphytic microorganisms in relation to plant disease. Annual Review of Phytopathology 3, 209-30.

LEBEN, C. (I97I). The bud in relation to the epiphytic microflora. In Ecology of Leaf Surface Micro-organisms, pp. 117-1 27. Edited by T. F. Preece \& C. H. Dickinson. London: Academic Press.

Leben, C. \& DAFT, G. C. (1967). Population variations of ephiphytic bacteria. Canadian Journal of Microbiology 13, I I 5 I-I I 56.

Ruinen, J. (196I). The phyllosphere. I. An ecologically neglected milieu. Plant and Soil 15, 8I-109.

SChmitthenNeR, A. F., Hoitink, H. A. J. \& KroeTz, M. E. (197I). Halo blight of mung bean incited by a new strain of Pseudomonas phaseolicola. Phytopathology 6I (Abstr.), 909.

Sinha, S. (1965). Microbiological complex of the phyllosphere and disease control. Indian Phytopathology I8, $1-20$.

Sleesman, J. P., Leben, C., Schmitthenner, A. F. \& Coyle, Elizabeth (1969). Relation of Pseudomonas glycinea to systemic toxemia in soybean seedlings. Phytopathology 59, 1970-1971. 